\title{
Pengembangan Media Pembelajaran Berbasis Role Playing Game Education Sebagai Bentuk Peningkatan Kualitas Pembelajaran Matematika
}

\author{
Arizal Fadli ${ }^{4}$, Suharno ${ }^{5}$, Ahmad Arif Musadad6 \\ tp10.32.arizal.fadli@gmail.com
}

\begin{abstract}
The purpose of this research is to determine the effectiveness of the application of interactive learning media based on role playing educational game in Mathematics for Class VII student learning outcomes MTS Negeri Kawunganten compared with conventional learning applied at the school. The method used in this research is the method of Research and Development study with sample class VII C and class VII D in MTS Negeri Kawunganten. The research design used is ADDIE. Based on the results of $t$-test analysis of the differences in the two averages the study, showed that the obtained $t$-test $=3.775$ while $t$-table $=2.033$. Because t-test $>t$-table then $\mathrm{H}_{0}$ is rejected, which means that the average class experiment better than the control class that student learning outcomes are given learning by using interactive learning media better than the learning outcomes through conventional learning model, with the word else, it proves that the media based interactive learning role playing educational game effectively to improve student learning outcomes in mathematics class VII in MTS Negeri Kawunganten..
\end{abstract}

Keywords: Mathematics, Learning Media, Role Play Game

\footnotetext{
${ }^{4}$ Mahasiswa Magister Teknologi Pendidikan Universitas Sebelas Maret Surakarta

5 Dosen Universitas Sebelas Maret Surakarta

${ }^{6}$ Dosen Universitas Sebelas Maret Surakarta
} 


\section{PENDAHULUAN}

$\mathrm{P}$ ada zaman sekarang perkembangan teknologi sudah menjadi hal yang wajar bagi masyarakat pada umumnya. Perkembangan teknologi yang begitu pesat memberi manfaat yang besar bagi masyarakat karena sudah masuk dalam segala aspek bidang tak terkecuali dalam bidang pendidikan. Hal ini dapat dilihat dalam sarana dan prasarana yang memanfaatan teknologi didalam pembelajaran kelas.

Dengan adanya kemajuan teknologi tentunya guru dituntut untuk selalu siap dan sigap mengikuti perkembangan agar siswa dapat menyerap pembelajaran dengan lebih baik dan mudah sehingga pembelajaran akan menjadi lebih efektif. Menurut Sinambela (2006), pembelajaran dikatakan efektif apabila mencapai sasaran yang diinginkan, baik dari segi tujuan pembelajaran maupun prestasi siswa yang maksimal. Pembelajaran efektif seperti ini akan sangat membantu dalam pembelajaran yang membutuhkan penalaran yang lebih seperti pembelajaran matematika.

Menurut Pitadjeng (2015) kebanyakan siswa menganggap bahwa matematika sulit dipelajari yang mengakibatkan ketakutan dan ketidak sukaan belajar matematika. Pada hal Matematika merupakan mata pelajaran pokok dan ilmu dasar yang harus dikuasai siswa. Dengan demikian Matematika harus ditanamkan secara mendalam kepada siswa. Setelah dilakukan observasi dan analisis kebutuhan pembelajaran matematik di MTS N Kawunganten yang dilakukan peneliti, dapat ditarik kesimpulan bahwa pembelajaran matematika disana masih menggunakan metode pembelajaran konvensional seperti ceramah, dan diskusi yang kurang diminati pesertadidik dikarena ketersediaan bahan ajar seperti media pembelajaran yang masih sangat terbatas. Keterbatasan bahan ajar seperti inilah yang membuat pembelajaran matematika menjadi kurang memotivasi dan menyenangkan bagi pesertadidik sehingga pembelajaran menjadi kurang efektif dan manjadi sulit diterima. agar pembelajaran matematika Matematika tidak selalu dianggap pelajaran yang sulit maka guru harus dapat mengembangkan bahan ajar yang dapat membantu peserta didik merasa mudah dalam mempelajari Matematika.

Penggunaan media dalam pembelajaran Matematika seharusnya dapat membatu meningkatkan minat dan motivasi serta efektivitas proses pembelajaran pesertadidik dalam memahami materi pembelajaran sebab media pembelajaran memiliki fungsi edukatif (Kustiono, 2010). Selain itu, menurut Arif (2017) mengatakan bahwa Penggunaan media pembelajaran dalam proses pembelajaran juga akan memberi kontribusi terhadap pengoptimalan pencapaian tujuan pembelajaran. Pengertian dari media pembelajaran sendiri merupakan setiap orang atau, bahan alat, atau peristiwa yang dapat menciptakan kondisi yang memungkinkan pembelajaran menerima penegetahuan dan sikap (Anitah, 2014). Pembelajaran berbasis media pembelajaran menempatkan pesertadidik untuk berinteraksi langsung dengan materi pembelajaran sesuai dengan kemampuan dan minat pesertadidik (Arsyad, 2013). Sehingga dapat meningkatkan dan mengarahkan perhatian anak yang dapat menimbulkan motivasi dan hasil belajar yang lebih baik.

Berdasarkan latar belakang di atas maka peneliti bermaksud untuk mengetahui keefektifan penerapan media pembelajaran interaktif berbasis role play game education pada mata pelajaran Matematika MTS N Kawunganten. karena hasil belajar peserta didik pembelajaran Matematika MTS N Kawunganten. belum maksimal yang disebabkan oleh kualitas pembelajaran Matematika MTS N Kawunganten belum maksimal dan kurang efektif baik dalam penyampaian materi maupun dalam menarik perhatian paserta didik untuk mempelajari pembelajaran matematika. Selain itu mata pelajaran 
Matematika merupakan mata pelajaran yang sulit dipahami sehingga peneliti perlu melaksanakan penelitian.

\section{METODE PENELITIAN}

Pada penelitian ini, metode penelitian yang digunakan adalah Research and Development, menurut Sugiono (2013) penelitian pengembangan merupakan metode penelitian yang digunakan untuk menghasilkan produk tertentu, dan menguji keefektifan produk tersebut.

Sedangkan model pembelajaran yang digunakan adalah menggunakan lima tahapan multimedia yang dikemukakan oleh Januszewski \& Molenda (2008) yaitu Analisis, Desain, Pengembangan, Implementasi dan Penilaian. Model pengembangan tersebut merupakan model pengembangan yang juga dikenal dengan model ADDIE.

Tahapan pertama dari model ADDIE adalah tahap analisis, tahap ini merupakan kegiatan analisis atau tahapan pengkajian. Analisis kebutuhan merupakan kegiatan ilmiah yang melibatkan berbagai teknik pengumpulan data dari berbagai sumber informasi untuk mengetahui kesenjangan (gap) antara keadaan yang seharusnya terjadi (ideal) dengan keadaan yang senyatanya terjadi (reality). Apabila kesenjangan tersebut dianggap sebagai suatu masalah yang memerlukan pemecahan maka kesenjangan tersebut dianggap sebagai suatu kebutuhan (needs). Tahapan kedua dari model ADDIE adalah tahap desain, tahap ini merupakan perancangan media berdasarkan hasil dari peremasalahan pada tahap pertama (analisis). Tahap desain meliputi tiga tahap yaitu penyusunan GBIM \& jabaran materi, pembuatan diagram alur dan storyboard. Tahapan ketiga dari model ADDIE adalah tahap pengembangan, Pada tahap ini mengembangkan multimedia sesuai dengan desain yang telah dibuat meliputi; (1) persiapan, (2) produksi, (3) pengujian produk. Tahapan keempat dari model ADDIE adalah tahap implementasi, Tahap ini dilakukan untuk menguji multimedia ini oleh pengguna di lapangan. Dalam penelitian ini tahapan yang dilalui meliputi; (1) uji coba kelompok kecil, (2) uji coba kelompok besar, (3) implementasi dalam pembelajaran. Tahapan kelima dari model ADDIE adalah tahap penilaian atau evaluasi, tahap ini Evaluasi dapat didefinisikan sebagai sebuah proses yang dilakukan untuk memberikan nilai terhadap program pembelajaran yang sudah dikembangkan

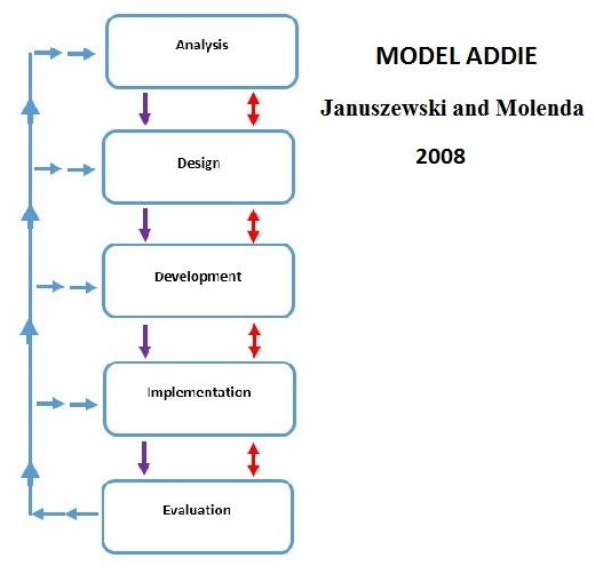

Gambar 1. Model Pengembangan ADDIE (2008)

Teknik pengumpulan data menggunakan hasil wawancara, observasi lapangan, angket, dan tes hasil belajar. 


\section{HASIL DAN PEMBAHASAN}

Pengembangan media pembelajaran berbasis role play game education yang telah dilaksanakan oleh peneliti menggunakan acuan model pengembangan produk ADDIE. Langkah-langkah pengembangan media pembelajaran berbasis role play game education

\section{Tahap Analisis}

Tahap ini Pengembangan media pembelajaran kearsipan digital diawali dengan analisis kebutuhan yang merupakan langkah pertama dalam melakukan pengembangan terhadap suatu media atau produk. Tahap analisis kebutuhan merupakan dasar dalam membuat suatu media. Tujuan dilakukannya analisis kebutuhan adalah untuk mendapatkan data pendukung pengembangan media yang dihasilkan sesuai dengan kebutuhan pengguna media. Uji coba penelitian dan pengembangan dilaksanakan di MTS N Kawunganten. Dengan menggunakan kelas VII A sebagai kelas uji coba dan kelas VII C sebahai Kelas.

Pada fase analisis kebutuhan berdasarkan hasil observasi yang dilakukan dapat disimpulkan bahwa guru masih menggunakan metode pembelajaran yang kurang diminati dan disukai oleh pesertadidik yang disebabkan kekurangan bahan ajar seperti media pembelajran berbasis game edukasi. Guru juga mengalami kesulitan dalam membuat media pembelajaran sehingga dalam memberikan contoh visual kepada siswa masih kurang maksimal. Oleh karena itu perlu adanya pengembangan media pembelajaran yang disesuaikan dengan materi pembelajaran Matematika di MTS N Kawunganten. Hal ini didukung dengan sarana dan prasarana yang memadai seperti LCD Proyektor, laptop atau komputer yang dapat dimanfaatkan dengan mudah dalam pembelajaran. Media ini bisa digunakan untuk media pembelajaran secara mandiri oleh siswa, diharapkan dengan pengembangan media pembelajaran berbasis role play game education siswa dapat menguasai materi dengan baik dan dapat memiliki motivasi lebih dalam belajar sehingga hasil belajar dapat meningkat.

\section{Tahap Desain}

Setelah mendapatkan data dari tahap analisis. Pada tahap ini, berdasarkan hasil analisis kebutuhan media yang diberikan kepada siswa dan guru, peneliti mulai merancang desain materi dan tujuan pembelajaran yang akan menjadi bahan dalam mengembangkan media pembelajaran berbasis game edukasi pada mata pelajaran matematika kelas 7 semester genap materi Aritmatika. Hasil dari tahap desian ini adalah sebuah materi pembelajaran, tujan pembelajaran, dan silabus yang digunakan untuk pembuatan media.

\section{Tahap Pengembangan}

Setelah tahap desain selesai, pada tahap ini peneliti membuat storyboard, naskah media lalu selanjutnya diteruskan dengan pembangunan media pembelajaran berbasis game. media dikembangkan yang harus mengacu pada desain dari tujuan pembelajaran yang telah dibuat. 
Jurnal Penelitian Teknologi Pendidikan http://jurnal.fkip.uns.ac.id/teknodika

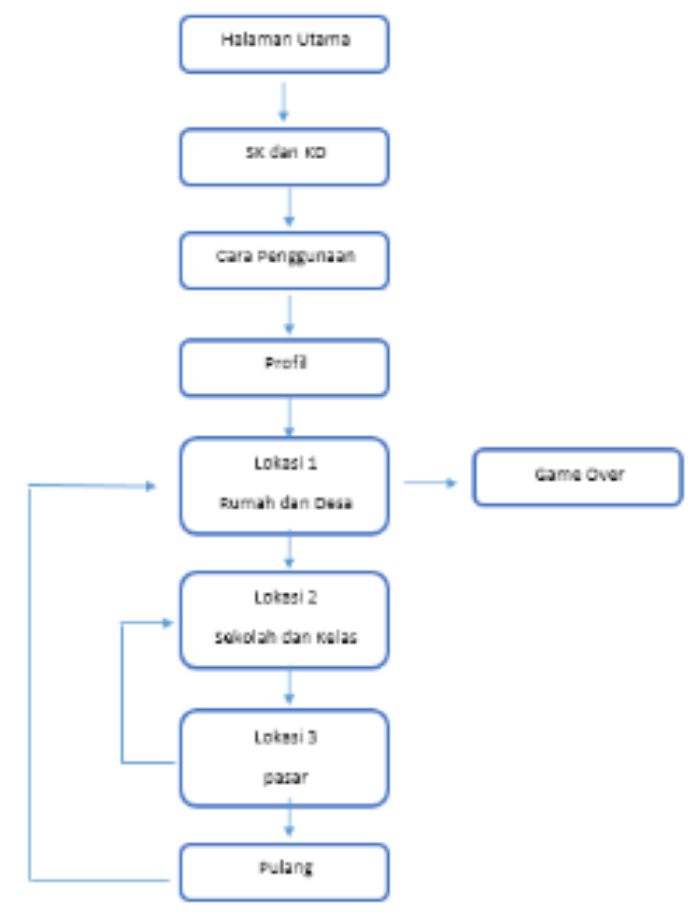

Gambar 2. Desain Storyboard Game Edukasi

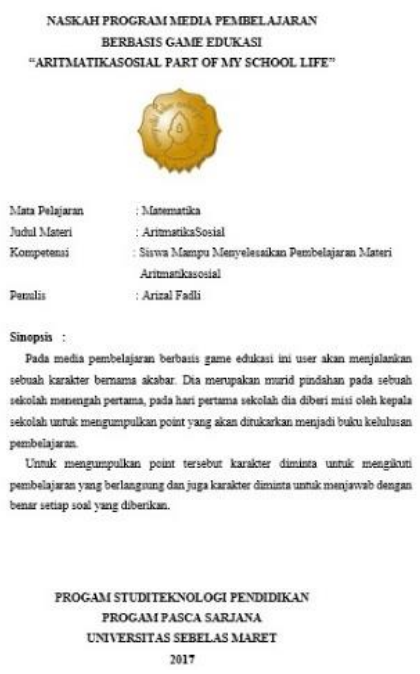

Gambar 3. Judul dan Sinopsis Progam 
Jurnal Penelitian Teknologi Pendidikan http://jurnal.fkip.uns.ac.id/teknodika

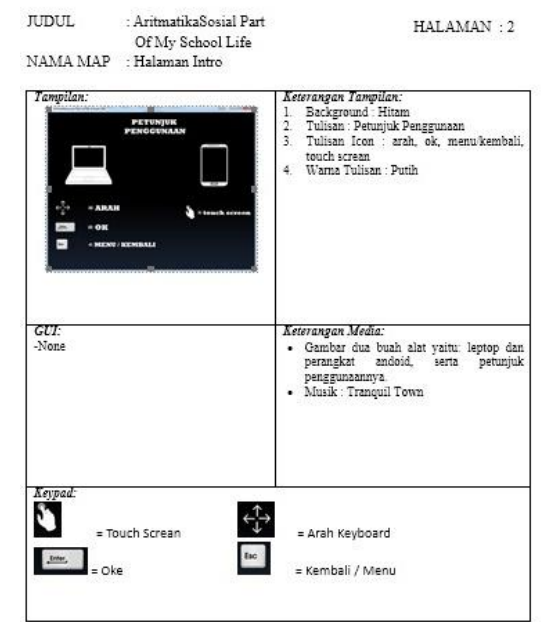

Gambar 4. Naskah Progam

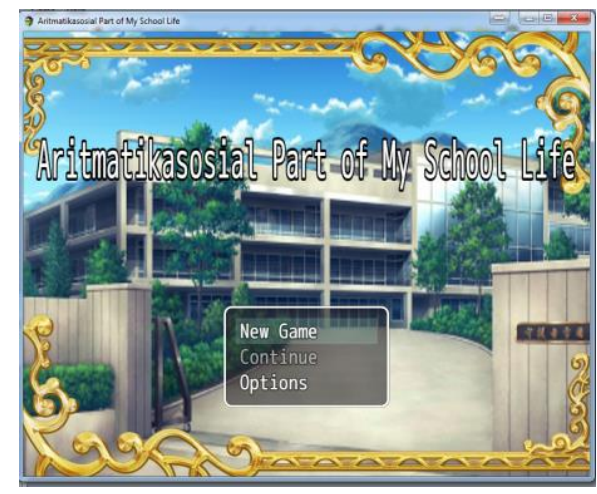

Gambar 5 Tampilan Menu Utama Game

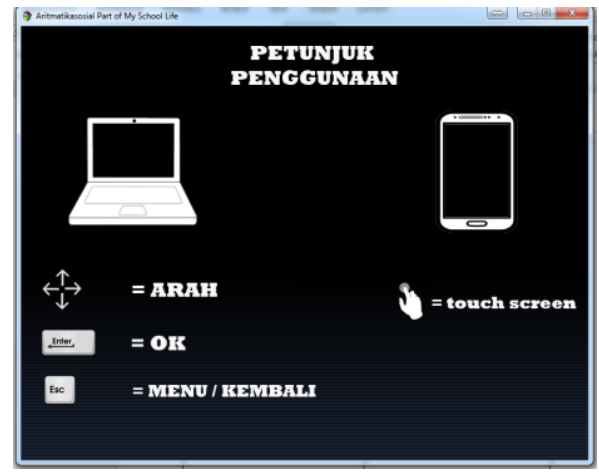

Gambar 6. Tampilan Petunjuk Penggunaan Game Edukasi 


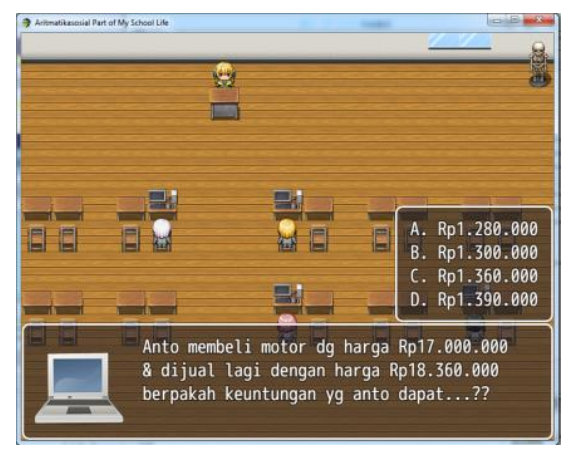

Gambar 7. Tampilan Game Edukasi pada saat Cerita Menjawab Soal di Ruang Kelas

\section{Tahap Implementasi}

Pada tahap ini, adalah media pembelajaran berbasis game edukasi yang sedang dikembangkan di uji cobakan kepada sekelompok siswa. untuk mengetahui dan mendapatkan tanggapan apakah media tersebut sudah sesuai dengan rancangan atau masih ada yang perlu diperbaiki.

\section{Tahap Evaluasi}

Tahap ini merupakan tahap akhir, dimana media pembelajaran berbasis game edukasi yang sudah dikembangkan diujikan kepada para ahli dan pakar. Pada penelitian ini untuk menguji apakah media ini layak atau tidak untuk digunakan menggunakan beberapa ahli dua ahli media dan satu ahli materi yang dimana para ahli ini sudah ekspert dimasing-masing bidangnya. Jika penilaian dari para ahli kurang maka akan direvisi dan diperbaiki lagi.

\section{HASIL DAN PEMBAHASAN}

Media pembelajaran berbasis Role play game education model pengembangan yang digunakan adalah model pengembangan produk pembelajaran ADDIE, Januszewski and Molenda (2008: 108) yaitu Analisis, Desain, Pengembangan, Implementasi dan Penilaian. Pada tahap pertama adalah analisis yang terdiri dari dua tahap yaitu studi pustaka dan analisis kebutuhan.

Pada tahap pertama peneliti melakukan analisis mengenai permasalahan untuk mengembangkan media pembelajaran berbasis role play game education, yaitu dengan cara melakukan observasi dan wawancara dengan guru mata pelajaran Matematika. Setelah menemukan permasalahan-permasalahan yang ditemukan di lapangan maka selanjutnya peneliti merumuskan tujuan dari pengembangan media pembelajaran role play game education. Berdasarkan hasil dari studi lapangan dan tahap analisis di ketahui permasalahan bahwa pembelajaran matematika guru di MTS N Kawunganten masih menggunakan metode pembelajaran konvensional seperti ceramah, dan diskusi yang kurang diminati pesertadidik dikarena ketersediaan bahan ajar seperti media pembelajaran yang masih sangat terbatas. Keterbatasan bahan ajar seperti inilah yang membuat pembelajaran matematika menjadi kurang memotivasi dan menyenangkan bagi pesertadidik sehingga pembelajaran menjadi kurang efektif dan manjadi sulit diterima.

Setanjutnya pada tahap kedua merupakan tahap desain dimana dari permasalahan yang telah didapat. peneliti lalu merubah menjadi materi dan tujuan belajar serta silabus pembelajaran. Diketahui dari hasil pengolahan didapatkan bahwa materi matematika yang akan digunakan sebagai materi pengembangan media pembelajaran berbasis role play games education adalah Aritmatikasosial 
dengan kopetensi inti: Memahami pengetahuan (faktual, konseptual, dan prosedural) berdasarkan rasa ingin tahunya tentang ilmu pengetahuan, teknologi, seni, budaya terkait fenomena dan kejadian tampak mata. Sedangkan kopetensi dasar: Menggunakan konsep aljabar dalam menyelesaikan masalah aritmatika sosial sederhana. Setelah itu dibuatlah storyboard sebagai konsep dasar dari jalan cerita yang akan digunakan dalam pengembangan game edukasi.

Pada tahap ketiga, merupakan tahap pengembangan. Pada tahap ini peneliti menyusun dan mengembangkan sebuah sinopsis, storyboard, dan naskah media pembelajaran berdasarkan materi dan tujuan pembelajaran yang telah dibuat. Dalam proses penyusunan peneliti berkonsultasi kepada ahli media dan ahli materi untuk menentukan arah jalan cerita. Sehingga madia pembelajaran berbasis game edukasi tidak keluar dari konteks pembelajaran. Setelah sinopsis, storyboard dan naskah media pembelajaran sudah jadi, pada tahap ini peneliti akan langsung melanjutkan pembuatan media pembelajaran menggunakan aplikasi RPG Maker MV untuk membuat game pembelajaran sesuai dengan rancangan yang telah dibuat. Aplikasi RPG Maker MV dipilih karena kemudahannya dalam dioperasikan, program ini telah menyediakan tileset untuk membuat peta, bahasa pemrogaman yang sederhana, dan sistem pertarungan. pada versi PC RPG maker dapat membuat tileset dan karakter baru, serta dapat menambahkan gambar-gambar baru untuk membuat game RPG sendiri. Menurut Seno $(2013$, p:09) RPG Maker merupakan sebuah program dikhususkan untuk membuat game RPG

Pada tahap keempat, merupakan tahap implementasi. Dimana media yang sudah jadi dirancang, selanjutnya akan diuji cobakan kepada kelompok uji coba pesertadidik guna mendapat respon apakah media yang dibuat sudah sesuai apatau masih ada yang perlu diperbaiki.

Tabel 1. Hasil Analsis Uji coba Produk

\begin{tabular}{lccc}
\hline Variabel & $\%$ & Rata-Rata & Kategori \\
\hline Aspek Program & 80,4 & & \\
Tampilan Program & 93,3 & & \\
Kualitas Teknis dan & & 83,71 & Baik \\
Keefektifan Program & 77,4 & & \\
& & & \\
\hline
\end{tabular}

Dari hasil uji coba diketahui bahwa para pesertadidik menanggapi bahwa media pembelajaran berbasis role play game education dinilai dari aspek program, tampilan program dan Kualitas Teknis dan Keefektifan Program dapat dikategorikan baik. Sehingga layak digunakan untuk pembelajaran matematika.

Tahap kelima, merupakan tahap evaluasi. Tahap ini merupakan tahap terakhir dimana media pembelajaran yang sudah dibuat dan dikembangkan diuji kepada ahli media, ahli materi dan pesertadidik. Penilaian ini dilakukan dengan cara memberikan angket kepada ahli media dan ahli materi lalu dianalisis secara deskriptif. Sedangkan kepada pesertadidik diberi tes lalu dianalisis menggunakan uji-t.

Dari hasil penilaian oleh ahli media terhadap media pembelajaran berbasis role play game education yang dikembangkan oleh peneliti. Dilihat dari Aspek Kemudahan Program rata-rata presentase yang didapat dari ahli media sebesar $86,7 \%$ dapat dikategorikan sangat baik karena media 
pembelajaran dalam pengoperasisaannya sudah memberikan Kemudahan penggunaan program dan Kemudahan dalam pengoprasian program.

Berdasarkan aspek kandungan kognisi rata-rata presentase yang didapat dari penilaian ahli media adalah $92,5 \%$ dapat dikategorikan sangat baik. Karena media pembelajaran yang dikembangkan dinilai memudahkan dalam penyampaian Isi materi pembelajaran serta antara kesesuaian Isi program dengan tujuan pembelajaran selaras.

Bedasarkan aspek presentasi informasi rata-rata presentase yang didapat dari penilaian ahli media adalah $100 \%$, dapat dikategorikan sangat baik. Karena media pembelajaran yang dikembangkan dinilai memiliki kebermafaatan program untuk membantu pesertadidik dalam memotivasi dan mengingat materi yang dipelajari, serta kebermanfaatan evalusi dalam program game edukasi dinilai sudah memenuhi kebutuhan pesertadidik.

Bedasarkan aspek integrasi media rata-rata presentase yang didapat dari penilaian ahli media adalah $100 \%$, dapat dikategorikan sangat baik. Karena media pembelajaran yang dikembangkan mempunyai kebermafaatan dalam membantu guru dan pesertadidik. Bedasarkan aspek artistik dan estetika rata-rata presentase yang didapat dari penilaian ahli media adalah $96,7 \%$, dapat dikategorikan sangat baik. Karena kesesuaian antara tampilan program dengan pembelajaran baik tampilan visual maupun audio visual dinilai pas dan bagus Bedasarkan aspek Fungsi Keseluruhan rata-rata presentase yang didapat dari penilaian ahli media adalah $90 \%$, dapat dikategorikan sangat baik. Karena fungsi keseluruhan program media dalam pembelajaran dinilai baik dan dapat membantu pesertadidik dalam pembelajaran.

Berdasarkan hasil olahan data ahli media, dilihat dari 6 aspek yang dinilai dan divalidasi maka diperoleh rata-rata hasil olahan sebesar $94,3 \%$ sehingga dikategorikan sangat baik dan sangat layak untuk digunakan kepada pesertadidik untuk meningkatkan kualitas pembelajaran matematika pada materi Aritmatikasosial. Selanjutnyan dari hasil penilaian yang dilakukan oleh ahli materi terhadap media pembelajaran berbasis role play game education yang dikembangkan oleh peneliti. Dinilai berdasarkan dari aspek kandungan kognisi rata-rata presentase yang didapat dari penilaian ahli materi adalah $93,3 \%$ dapat dikategorikan sangat baik. Karena materi yang terkandung didalam media pembeljaran dinilai memudahkan dalam penyampaian Isi materi pembelajaran serta antara kesesuaian Isi program dengan tujuan pembelajaran selaras. Berdasarkan dari aspek Keterkaitan Kompetensi Dasar rata-rata presentase yang didapat dari penilaian ahli materi adalah $93 \%$ dapat dikategorikan sangat baik. Karena materi dan jalan cerita yang terdapat dalam media pembelajaran sesuai dengan kopetensi dasar dari materi aritmatika sosial. Berdasarkan dari aspek Akurasi Materi rata-rata presentase yang didapat dari penilaian ahli materi adalah 93\% dapat dikategorikan sangat baik. Karena materi yang terdapat dalam media pembelajaran sudah mencakup isi pokok dari materi pembelajaran aritmatikasosial. Berdasarkan dari aspek Penyajian Pembelajaran rata-rata presentase yang didapat dari penilaian ahli materi adalah $90 \%$ dapat dikategorikan sangat baik. Karena dalam menyajikan materi pembelajaran media pembelajaran yang dibuat dapat menampilkan materi secara baik sehingga materi dapat diterima dengan mudah dan tidak membuat multitafsir.

Berdasarkan dari aspek Komunikatif dan Interaktif rata-rata presentase yang didapat dari penilaian ahli materi adalah $100 \%$ dapat dikategorikan sangat baik. Karena isi materi didalam media dinilai dapat memberikan interaksi kepada pesertadidik untuk mempermudah memahami materi serta memotivasi pesertadidik untuk terus belajar tanpa merasa jenuh. Berdasarkan dari aspek Aspek Bahasa rata-rata presentase yang didapat dari penilaian ahli materi adalah $100 \%$ dapat dikategorikan 
sangat baik. Karena bahasa yang diguinakan media pembelajaran dalam menyampaikan materi julas dan tidak menimbulkan kebingungan sehingga dapat memudahkan pesertadidik dalam memahami materi pembelajaran. Berdasarkan hasil olahan data ahli materi, dilihat dari 6 aspek yang dinilai dan divalidasi maka diperoleh rata-rata hasil olahan sebesar $94,77 \%$ sehingga dikategorikan sangat baik dan sangat layak untuk digunakan kepada pesertadidik untuk meningkatkan kualitas pembelajaran matematika pada materi Aritmatikasosial.

Selanjutnya Untuk mengetahui efektivitas media pembelajaran berbasis game edukasi terhadap siswa peneliti melakukan analisis dengan menggunakan uji-t yang diberikan kepada kelas kontrol dan kelas eksperimen. Pengambilan data dilakukan dengan cara dua tahap, tahap pretest yaitu sebelum diberi perlakuan dan setelah diberi perlakuan yaitu posttest. Berdasarkan hasil pretest yang dilakukan peneliti melakukan uji normalitas terhadap data awal (pretest) diperoleh bahwa kelas eksperimen dan kelas kontrol berdistribusi normal. Setelah itu dilakukan uji homogenitas untuk mengetahui apakah populasi memiliki varians yang sama atau tidak, Hasilnya Uji-F menunjukkan bahwa populasi memiliki varians yang sama (homogen). Karena data pretest menunjukkan normal dan homogen, maka dilanjutkan dengan Uji-t untuk mengetahui apakah sampel penelitian memiliki perbedaan kemampuan awal yang signifikan atau tidak. Hasil Uji-t menunjukkan bahwa tidak terdapat perbedaan kemampuan awal yang signifikan diantara ketiga kelas yang dijadikan sampel penelitian. Dari semua uji yang telah dilakukan tersebut menunjukkan bahwa kedua kelas sampel penelitian memiliki kondisi awal yang sama. Hal ini terlihat pada hasil perhitungan uji t data awal dibawah ini.

Tabel 2. Hasil Perhitungan Uji-t Data awal atau data Pre Test

\begin{tabular}{|c|c|c|c|c|c|}
\hline Kelas & Rata-rata & Dk & thitung & $t_{\text {tabel }}$ & Kriteria \\
\hline Eksperimen & 45,9 & 33,0 & \multirow{2}{*}{0,07} & 2,033 & $\begin{array}{r}\text { Tidak ada } \\
\text { perbedaan }\end{array}$ \\
\hline Kontrol & 59,7 & 33,0 & & \\
\hline
\end{tabular}

Selanjutnya peneliti mengambil data untuk mengetahui manakah hasil belajar yang lebih baik atau lebih efektif antara pembelajaran konvensional dengan pembelajaran yang menggunakan media pembelajaran berbasis role play game education. Data ini diperoleh dari uji perbedaan rata-rata atau Uji-t pada data posttest. Hasil perhitungan Uji-t data akhir dengan menggunakan data post-test belajar Matematika pada kelas yang menggunakan media pembelajaran interakif dengan kelas yang menggunakan pembelajaran konvensional secara berturut-turut terlihat pada hasil perhitungan Uji-t data akhir (post-test) dibawah ini.

Tabel 3. Hasil Perhitungan Uji Perbedaan Dua Rata-Rata Data Post-test

\begin{tabular}{|c|c|c|c|c|c|}
\hline Kelas & Rata-rata & $\mathrm{dk}$ & thitung & $\mathrm{t}_{\text {tabel }}$ & Kriteria \\
\hline Eksperimen & 75,9 & 33,0 & \multirow{2}{*}{3,775} & 2,033 & ada perbedaan \\
\hline Kontrol & 66,6 & 33,0 & & & \\
\hline
\end{tabular}

Berdasarkan perhitungan uji perbedaan rata-rata antara kelas eksperimen dengan kelas kontrol, diperoleh t-hitung $=3,775$ sedangkan $\mathrm{t}$-tabel $=2,033$. Karena t-hitung $>$ t-tabel maka Ho ditolak yang 
berarti bahwa rata-rata kelas eksperimen lebih baik dari pada kelas kontrol sehingga hasil belajar siswa yang diberi pembelajaran menggunakan media pembelajaran interaktif lebih baik dari pada hasil belajar melalui model pembelajaran konvensional. Hal ini didukung dengan hasil penelitian Arif Arif, Cicilia, \& Andre (2017, p:79) menyatakan bahwa berdasarkan uji-t Hasil penelitian menunjukkan bahwa keefektifan dari media pembelajaran kearsipan digital bahwa thitung $>$ ttabel $=(3,26>2,00)$ yang berarti $\mathrm{H}_{0}$ ditolak dan $\mathrm{H}_{1}$ diterima, artinya ada pengaruh yang signifikan antara penggunaan media pembelajaran terhadap hasil belajar siswa dalam pembelajaran di SMK Negeri 3 Surakarta. Selanjutnya hasil penelitian yang dilakukan oleh

Berdasarkan uraian tersebut, dapat kita ketahui bahwa penggunaan media pembelajaran berbasis role play game terbukti efektif dalam meningkatkan kualitas pembelajaran dan hasil belajar siswa pada mata pelajaran Matematika. karena media pembelajaran merupakan salah satu sarana yang sangat mendukung dalam pengembangan ilmu pengetahuan yang dimiliki oleh seseorang, terutama dalam proses pembelajaran pada mata pelajaran yang membutuhkan penalaran yang lebih Seperti matematika. Sehingga, seharusnya pihak sekolah hendaknya lebih memperhatikan dan menyediakan media pendidikan secara lengkap agar proses pembelajaran di kelas dapat berjalan dengan efektif, karena siswa lebih termotivasi untuk belajar sambil bermain. Selain itu, pelajaran juga lebih mudah dipahami sehingga pada saat ulangan harian dan ujian semester siswa dapat menjawab soal-soal ujian.

\section{KESIMPULAN}

Media pembelajaran berbasis role play game education terbukti dapat meningkatkan hasil belajar siswa. Keefektifan media pembelajaran didasarkan pada hasil pretest (sebelum menggunakan media pembelajaran berbasis role play game education) diperoleh rata-rata nilai 45,9 dan posttest (sesudah menggunakan media pembelajaran berbasis role play game education) diperoleh rata-rata 75,9 pada saat uji coba lapangan. Kenaikan rata-rata nilai hasil belajar pretest (sebelum) dan posttest (sesudah) menggunakan media pembelajaran berbasis role play game education menunjukkan bahwa media pembelajaran berbasis role play game education efektif dalam meningkatkan hasil belajar siswa. Penggunaan media pembelajaran berbasis role play game education efektif meningkatkan hasil belajar siswa didukung oleh perhitungan postest (setelah diberi perlakuan) yang didapat dari perhitungan statistik diperoleh t-hitung $=3,775$ sedangkan t-tabel $=2,033$. Karena t-hitung $>$ t-tabel maka Ho ditolak yang berarti bahwa rata-rata kelas eksperimen lebih baik dari pada kelas kontrol sehingga hasil belajar siswa yang diberi pembelajaran menggunakan media pembelajaran interaktif lebih baik dari pada hasil belajar melalui model pembelajaran konvensional.

\section{SARAN- SARAN}

Berdasarkan hasil penelitian yang di lakukan peneliti. Maka ada beberapa saran-saran yang dapat dikemukakan sebagai berikut:

1. Untuk sekolah

Pihak sekolah hendaknya lebih meningkatkan sarana dan fasilitas serta meningkatkan pengawasan dalam memelihara sarana dan fasilitas guna menunjang proses pembelajaran terutama komputer dan LCD serta pendingin ruangan.

2. Untuk guru 
Guru hendaknya dapat menerapkan media pembelajaran yang bervariasi dalam pembelajaran matematika agar proses pembelajaran tidak monoton dan membosankan, sebagai alternatifnya adalah dengan menggunakan media pembelajaran berbasis role play game education.

3. Untuk peserta didik

Peserta didik hendaknya lebih fokus dan aktif dalam mengikuti pembelajaran matematika di kelas dan menggunakan media pembelajaran berbasis role play game education untuk membantu proses pemahaman materi dalam pembelajaran agar lebih menyenangkan. serta perlu ditingkatkan

\section{DAFTAR PUSTAKA}

Arif, W. W., Cicilia, D. I., \& Andre, N. R. (2017). Pengembangan Media Pembelajaran Kearsipan Digital Untuk Meningkatkan Hasil Belajar Siswa Smk Negeri 3 Surakarta. Jurnal Pendidikan Vokasi 7, pp. 78-86.: http://journal.uny.ac.id/index.php/jpv/article/view/12879. 2017.04.002

Arsyad, A. (2013). Media Pembelajaran. Jakarta: PT Rajagrafindo Persada.

Januszewski, A. \& Molenda, M. (2008). Educational Technology, A Difinition With Commentary. New York: Lawrence Erlbaum Associates, Taylor \& Francis Group.

Kustiono. (2010). Media Pembelajaran Konsep, Nilai Edukatif, Klasifikasi, Praktek Pemanfaatan dan Pengembangan. Semarang: UNNES Press.

Pitadjeng. (2015). Pembelajaran Matematika yang Menyenangkan. Yogyakarta: Graha Ilmu.

Anitah, S. (2014). Media pembelajaran. Surakarta: UNS Press.

Sewo, W. (Ed). (2013). Membuat Game RPG Dengan RPG Maker. Yogyakarta: CV Andi.

Sugiyono. (2010). Metode Penelitian Pendidikan Pendekatan Kuantitatif, Kualitatif, Dan R\&D. Jakarta:

Suyitno. (2016). Pengembangan Multimedia Interaktif Pengukuran Teknik Untuk Meningkatkan Hasil Belajar Siswa SMK, 23, 101-109.: 